\title{
Nematodes in Horticulture: An Overview
}

\author{
Lopes-Caitar VS ${ }^{1}$, Pinheiro JB ${ }^{2}$ and Marcelino-Guimarães FC $^{* 1}$ \\ ${ }^{1}$ Brazilian Agricultural Research Corporation - EMBRAPA Soybean, Londrina, Paraná, Brazil \\ ${ }^{2}$ Brazilian Agricultural Research Corporation - EMBRAPA Vegetables, Brasília, Distrito Federal, Brazil
}

${ }^{*}$ Corresponding author: Marcelino-Guimarães FC, Brazilian Agricultural Research Corporation - EMBRAPA Soybean, Londrina, Paraná, Brazil, Tel: +55 43 3371.6265, E-mail: francismar.marcelino@embrapa.br

Citation: Lopes-Caitar VS, Pinheiro JB, Marcelino-Guimarães FC (2019) Nematodes in Horticulture: An Overview. J Horti Sci \& Crop Res 1(1): 105

Received Date: April 17, 2019 Accepted Date: May 28, 2019 Published Date: May 30, 2019

\begin{abstract}
Most important studies about plant-parasitic nematode have been performed especially for major crops, such as soybean, rice, corn, and wheat. However, the damage caused by these pathogens in general horticulture should have more attention. Nowadays, horticulture yield results have been relevant, allowing to show its worldwide power in economies and food. In addition, human hunger and diets changes have highlighted the current horticulture scenario and increased efforts towards solutions in diseases and losses caused by phytopathogens. Nematode infection has been the cause of important yield losses in horticulture and the genus Meloidogyne and Pratylenchus are reported to be the most important threats. In addition, as horticulture is associated with a wide number of products, the compilation of information regarding damages, symptoms, resistance, novel solutions and other concepts for phynematode management allows for the better comprehension of the whole situation. Herein, we integrated information about the damage and losses caused by these pathogens in horticulture. Resistant genotypes seem to be the best alternative and, due to wide horticulture aspect, the focus is especially for life sustaining horticultural, such as banana, cassava, potato, and sugar beet. In addition, it was also provided evidence regarding how studies have been conducted on new strategies for resistance and control, such as the elucidation of effector's functions. Nematode effectors studies, focus on the development of new resistant plant genotypes, is an auspicious strategy against this parasites.
\end{abstract}

Keywords: Fruit and Vegetables; Life-Sustaining; Management Strategies; Yield Losses

\section{Horticulture Global Scenario}

Plants are fundamental to the existence of life on Earth and have a wide spectrum of uses, but the most obvious is for human sustenance [1]. Plants supply all of our food demands, directly or indirectly, as animal food intermediaries. The intensive use of plants for people is the definition of horticulture. Its origins are inseparable from the beginnings of agriculture [2]. Horticultural practices, by occidental native people, began independently in several regions of the continent. Records indicate the occurrence of pumpkin and pepper crops in approximately 7,000 B.C. in America, even before the first corn crops, which occurred in approximately 2,500 B.C. [3]. Egypt's papyri list many wines, medicinal plants and their associated drugs in approximately 3,150 B.C. [2].

Horticulture is a widely used term that presents four main subdivisions: pomology or fruticulture (tree fruits and nut crops), olericulture (vegetable production), floriculture and the landscape and nursery industry [4]. The variety of species in horticulture enables its application under different agro-climatic conditions and soil features, allowing rising incomes and employment generation. At a global level, horticulture is a sector in full expansion and vaporization [5,6]. According to the Food and Agriculture Organization of the United Nations [7], fruit and vegetables production around the world increased from 69 million tons in 1995 to 137 million tons in 2016. Global olericulture production includes cauliflower, lettuce, celery, beans, peas, cassava and others. However, potato is the most widespread and abundant horticultural product around the world, followed by tomato, onion and cabbage [8]. China, India and Nigeria are the dominant vegetable producers. Melons are the most commonly produced fruit, followed by bananas, apples and grapes [6]. China, India and Brazil are the dominant fruit producers. These countries are responsible for approximately $50 \%$ of the world's fruit production and $65 \%$ of the world's vegetable production. Of the total global annual consumption of flowers, approximately $80 \%$ is concentrated in Western Europe, Germany, the USA, the UK, France, the Netherlands and Switzerland, and these locations are the dominant producers, starting with the Netherlands, the USA and Sweden. 
Although it is unquestionable how important world horticultural advances are in terms of quality and production over recent years, we still stand at a crossroads. We all need to understand that horticulture has other benefits, as well. Currently, more than two billion people, the majority in developing countries, are suffering from hunger and micronutrient deficiencies. Additionally, the forecast for the world population in 2050 is approximately 9 billion people [9]. Another important factor boosting horticultural production is world dietary pattern changes. People are increasingly conscious about their diet, health, and quality of life [10, 11]. Vegetarian and vegan habits have been widely disseminated and are adhered to worldwide, whether for religious, cultural or ethical reasons. Therefore, it appears that the world needs a new 'green revolution' [12].

Therefore, all the efforts to increase world horticulture production will be essential for feeding the future. These efforts will help improve world human health, playing a vital role in solving the global malnutrition problem, increasing incomes and generating job opportunities. We still have so many challenges to overcome to achieve the full potential that this agricultural sector can show. The stress caused by biotic and abiotic factors has significantly limited greater results in horticultural production. Nematodes are one of the main problems among all plant pathogens, not only by suppressing plant growth but also by adversely affecting the overall yield [13].

\section{An Overview of Nematode Parasitism in Horticulture}

Among all phytopathogens, plant parasitic nematodes (PPN) are an important cause of yield losses and food security issues. PPN cause losses estimated at $14.6 \%$ of the total production of all tropical and subtropical crops. This means an estimated annual economic loss of more than US \$ 173 billion worldwide and consequently a significant impact on the world population's food [14]. Due to their nonspecific symptoms, horticultural losses caused by nematodes are often underestimated. The annual yield loss of the world's major horticultural crops due to nematode infections has been estimated to be $12 \%$ for fruit and nut crops, $11 \%$ for vegetables, and 10\% for ornamental crops. These losses result in more than US \$ 30 billion in costs to life sustaining and other important horticultural crops [15]. Based on a survey of the literature, Table 1 shows estimated annual yield loss details due to nematode infection of horticulture crops.

\begin{tabular}{|c|c|c|}
\hline Horticulture crops & Annual Loss (\%) & Reference \\
\hline Banana (Musa spp.) & $19-30$ & $\begin{array}{c}\text { (Brentu et al. 2004; Sasser and Freckman } \\
\text { 1987) }\end{array}$ \\
\hline Bean (Phaseolus vulgaris) & $27-60$ & $\begin{array}{l}\text { (Kimenju et al. 1999; Singh and Kumar } \\
\text { 2015) }\end{array}$ \\
\hline Beet (Beta vulgaris) & $12-60$ & (Singh and Kumar 2015; Syngenta 2010) \\
\hline Bitter gourd (Momordica charantia) & $4-48$ & $\begin{array}{l}\text { (Ali 1997; Anwar and McKenry 2012; } \\
\text { Kaur and Pathak 2001) }\end{array}$ \\
\hline Cabbage (Brassica oleracea var. Capitata) & $2-24$ & $\begin{array}{c}\text { (Anwar and McKenry 2012; Olthof et al. } \\
\text { 1974; Singh and Kumar 2015) }\end{array}$ \\
\hline Carrot (Daucus carota) & $25-50$ & $\begin{array}{c}\text { (Anwar and McKenry 2012; Bossis et al. } \\
\text { 1989; Singh and Kumar 2015) }\end{array}$ \\
\hline Citrus (Citrus ssp.) & $4-70$ & $\begin{array}{c}\text { (Brooks 2008; Sasser and Freckman } \\
\text { 1987) }\end{array}$ \\
\hline Chickpea (Cicer arietinum) & $14-60$ & $\begin{array}{l}\text { (Ali and Sharma 2003; Das 2015; Sasser } \\
\text { and Freckman 1987) }\end{array}$ \\
\hline Chilies (Capsicum annuum) & $19-70$ & $\begin{array}{l}\text { Ali, 1997; Anwar and McKenry, 2012; } \\
\text { Singh and Kumar, } 2015\end{array}$ \\
\hline Cowpea (Vigna sinensis) & $15-71$ & $\begin{array}{l}\text { (Ali 1997; Sasser and Freckman 1987; } \\
\text { Singh and Kumar 2015) }\end{array}$ \\
\hline Cucumber (Cucumis sativus) & $25-88$ & $\begin{array}{l}\text { (Anwar and McKenry 2012; Giné et al. } \\
\text { 2014) }\end{array}$ \\
\hline Eggplant (Solanum melongena) & $17-43$ & $\begin{array}{c}\text { (Anwar and McKenry 2012; Singh and } \\
\text { Kumar 2015) }\end{array}$ \\
\hline Garlic (Allium sativum) & $60-80$ & (Sturhan and Brzeski 1991) \\
\hline Ginger (Zingiber officinale) & $51-74$ & (Ali 1997) \\
\hline Grape (Vitis ssp.) & $12-80$ & $\begin{array}{c}\text { (Brooks 2008; Sasser and Freckman } \\
\text { 1987) }\end{array}$ \\
\hline Peanut (Arachis hypogaea) & $13-70$ & (Mc Donald et al. 2005; Patel et al. 1996) \\
\hline Lettuce (Lactuca sativa) & $10-64$ & $\begin{array}{c}\text { (Olthof et al. 1974; Viaene and Abawi } \\
\text { 1996) }\end{array}$ \\
\hline Melon (Cucumis melo) & $14-45$ & $\begin{array}{l}\text { (Anwar and McKenry 2012; Kim and } \\
\text { Ferris 2002; Sasser and Freckman 1987) }\end{array}$ \\
\hline
\end{tabular}




\begin{tabular}{|c|c|c|}
\hline Horticulture crops & Annual Loss (\%) & Reference \\
\hline Mushroom (Agaricus bisporus) & $13-70$ & (Aman et al. 2002; Kumar et al. 2010) \\
\hline Okra (Abelmoschus esculentus) & $20-90$ & $\begin{array}{l}\text { (Ali 1997; Devi et al. 2011; Sasser and } \\
\text { Freckman 1987) }\end{array}$ \\
\hline Onion (Allium cepa) & $60-80$ & (Sturhan and Brzeski 1991) \\
\hline Ornamentals & $11-84$ & (Ali 1997; Sasser and Freckman 1987) \\
\hline Pea (Pisum sativum) & $20-85$ & $\begin{array}{c}\text { (Greco et al. 1991; Greco and VITO } \\
\text { 1994; Singh and Kumar 2015) }\end{array}$ \\
\hline Pigeon pea (Cajanus cajan) & $13-67$ & $\begin{array}{l}\text { (Saxen and Reddy } 1987 \text {; Sharma et al. } \\
\text { 1993) }\end{array}$ \\
\hline Potato (Solanum tuberosum) & $12-85$ & $\begin{array}{c}\text { (Anwar and McKenry 2012; Greco et al. } \\
1984 \text { ) }\end{array}$ \\
\hline Pumpkin (Cucurbita spp.) & 27 & $\begin{array}{c}\text { (Anwar and McKenry 2012; Singh and } \\
\text { Kumar 2015) }\end{array}$ \\
\hline Spinach (Spinacea oleracea) & $25-49$ & $\begin{array}{l}\text { (Anwar and McKenry 2012; Olthof et } \\
\text { al. 1974) }\end{array}$ \\
\hline Sponge gourd (Luffa cylindrica) & 15 & $\begin{array}{c}\text { (Anwar and McKenry 2012; Singh and } \\
\text { Kumar 2015) }\end{array}$ \\
\hline Strawberry (Fragaria. ssp.) & $60-80$ & (Bohmer 1981; Mohotti et al. 1997) \\
\hline Tobacco (Nicotiana spp.) & $14-60$ & $\begin{array}{c}\text { (LaMondia 2002; Sasser and Freckman } \\
\text { 1987) }\end{array}$ \\
\hline Tomato (Solanum lycopersicum) & $20-85$ & (K. R et al. 1976; Singh and Kumar 2015) \\
\hline Watermelon (Citrullus lanatus) & $12-37$ & (López-Gómez et al. 2014) \\
\hline Yam (Dioscorea spp.) & $17-85$ & $\begin{array}{c}\text { (Amusa et al. 2004; Singh and Kumar } \\
\text { 2015) }\end{array}$ \\
\hline
\end{tabular}

Table 1: Percentage of Annual Yield Losses Associated with Nematode Infection in Horticulture Crops

As stated previously, PPN feed mainly on underground higher plant tissues, such as roots, rhizomes, tubers, bulbs and hypogeous fruits. Hence, they are considered to be 'invisible enemies', as the plant symptoms occur on the aerial parts and are often confused with those from abiotic stress, such as lack of nitrogen or water deficit. However, some other nematode species can feed on organs such as stems, leaves, flowers, fruits and seeds. In addition to the lack of specific symptoms, there are some situations where it is difficult to identify the presence of nematodes only by eye, especially when they are not sedentary [16].

Some nematode species have greater importance for commodity crops, such as Meloidogyne spp., Heterodera spp., Globodera spp., Pratylenchus spp., Radopholus similis, Ditylenchus dipsaci, Bursaphelenchus xylophilus, Rotylenchulus reniformis, Xiphinema index, Nacobbus aberrans, and Aphelenchoides besseyi [17]. Some PPN are highly polyphagous, such as Meloidogyne spp. and Pratylenchus spp., which can infect many species of plants [18]. However, in horticulture crops, this situation can be quite different, depending upon nematode population density, environmental factors, and especially the most dense horticulture crop in a specific location and its susceptibility or tolerance to infection. In the Philippines, for example, at least 13 genera of PPN were found to be associated with 15 semi-temperate vegetables [19]. The top nematode threats in horticulture crops are described above but also include Tylenchulus spp., Helicotylenchus spp., Trichodorus spp., Longidorus spp. and many others.

\section{Meloidogyne spp. (Root-Knot Nematode - RKN)}

The Meloidogyne genus is represented by close to 100 recognized valid species, and M. incognita, M. javanica, M. arenaria, and M. hapla are the most important ones [14]. Root-knot nematodes are major pests of horticultural crops and are able to infect more than 50 different horticultural plant species. Meloidogyne is a cosmopolitan genus, but its distribution is more common in temperate, subtropical, and tropical areas [20]. Three major successful features of this genus can be described: an elaborate parasitism strategy (induction of the host root cells to differentiate into nurse cells, which allows its development and reproduction), female morphology (its pear shape and sedentary behaviour allows the presence of two ovaries and the development of a large amount of eggs (average 400 eggs)), and different reproductive approaches (sexual and asexual reproduction). Even in male-independent reproduction, egg development is an energy-saving strategy [14]. The Meloidogyne life cycle consists of six developmental stages: egg, four larval stages (juvenile) and adult, taking approximately 25 days for completion. Once the second larval stage (J2) is attained, all the following stages are actively infectious, meaning that they are able to penetrate and parasite the host cells [21,22].

Infection by root-knot nematodes relies on the development of specialized feeding cells in the vascular cylinder, endoderm and cortex areas, called giant or nurse cells. During this process, there is also a hyperplastic and hypertrophic cell response in the infected area that causes root thickening, and each crop can respond differently. However, in the end, this process always culminates in gall development, which can compress xylem vessel elements, resulting in vascular cylinder disorganization and therefore interference in absorption and internal solute transport [23]. 
Many vegetable crops are susceptible to Meloidogyne spp., particularly potato (Solanum tuberosum), tomato (Solanum lycopersicum), carrot (Daucus carota), lettuce (Lactuca sativa), aubergine, okra, cucumber, and gourds. The first symptoms of root-knot infection in tubers may be internal, but external symptoms are visible $\sim 2$ months later, with the appearance of galls on the surface. Galls can give a rough appearance to the surface and may be accompanied by cracks to large, isolated lumps [24]. The tubers show a 'popcorn-like' or 'pimple-like' structure with an associated rotted aspect due to starch loss in the tissue (Figure 1) [25]. Although visual diagnoses after a high level of infection can be easily performed, the extraction method improves the early detection of rootknot infection [26]. The root-knot damage in potato can be recognized by plants withering even in moist soil, yellowed leaves and growth problems [27]. Meloidogyne hapla causes more root gall proliferation in potato, while M. arenaria, M. incognita, and M. javanica cause knobbly tubers in addition to root galls. Root-knot infection symptoms in ginger include gall formation, but it is especially characterized by rhizome damage showing unusual brown to black lesions with an associated layer of accumulated fluid $[25,28]$. In carrots, infection results in excessive root growth, forking formations and galls around the lateral roots, while beadlike galls occur in the outward appearance of lettuce, and obvious galls can be easily observed in okra and pumpkin roots (Figure 2) $[25,29,30]$.

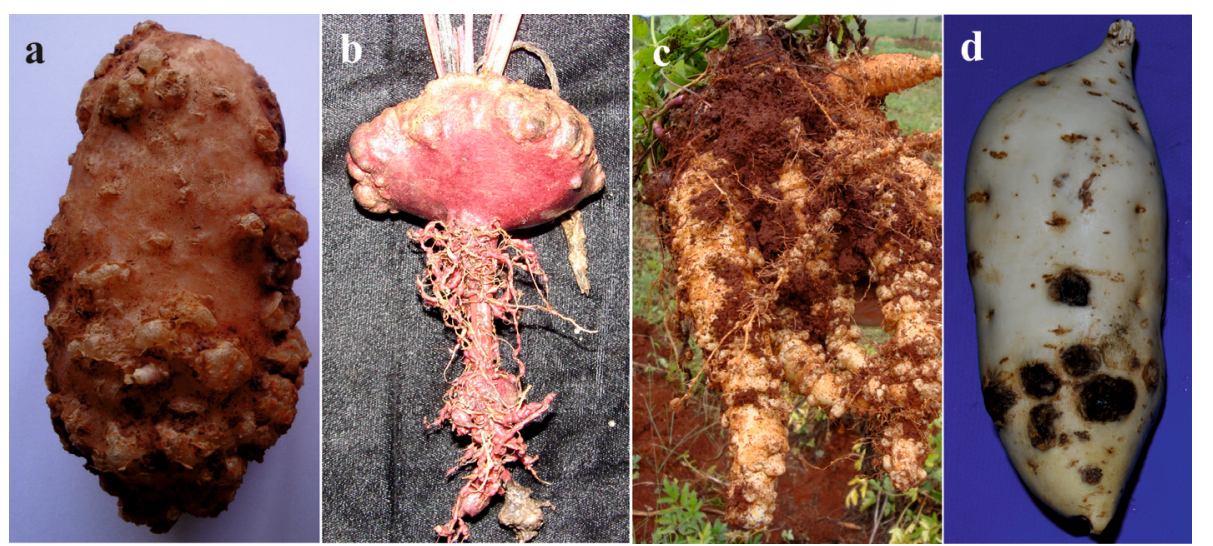

Figure 1: (a) Tuber symptoms caused by Meloidogyne spp. show a 'popcorn-like' structure in potato; (b) sugar beet; (c) Peruvian carrot, (d) and sweet potato
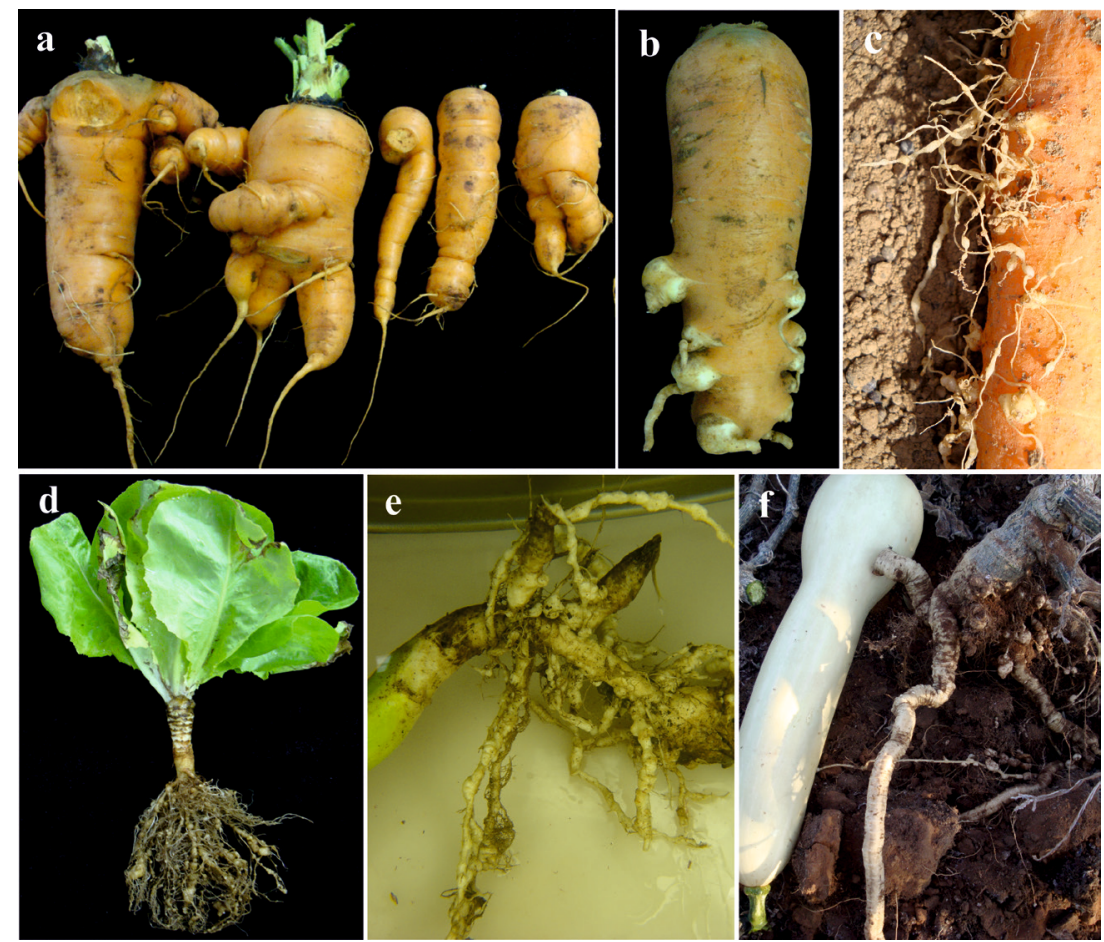

Figure 2: (a) Symptoms caused by Meloidogyne spp. infection in carrots show bifurcation and protuberances; (b) evident gall formation; (c) and galls in carrot secondary roots; (d) galls in lettuce roots; (e) galls in okra roots; (f) and big galls pumpkin roots.

Other important cultures affected by Meloidogyne infection are gilo, cabbage, pepper and melon, all presenting evident gall formation, affecting their development and production (Figure 3). Moreover, the damage caused to the roots and tubers (galls and injuries) are generally very compromising in terms of plant development [31]. Some cultures that are more uncommonly parasitized by other nematode species but are good hosts to Meloidogyne nematodes are bell pepper (Capsicum annuum), black pepper (Piper nigrum), garlic (Allium sativum), and onion (Allium cepa). 

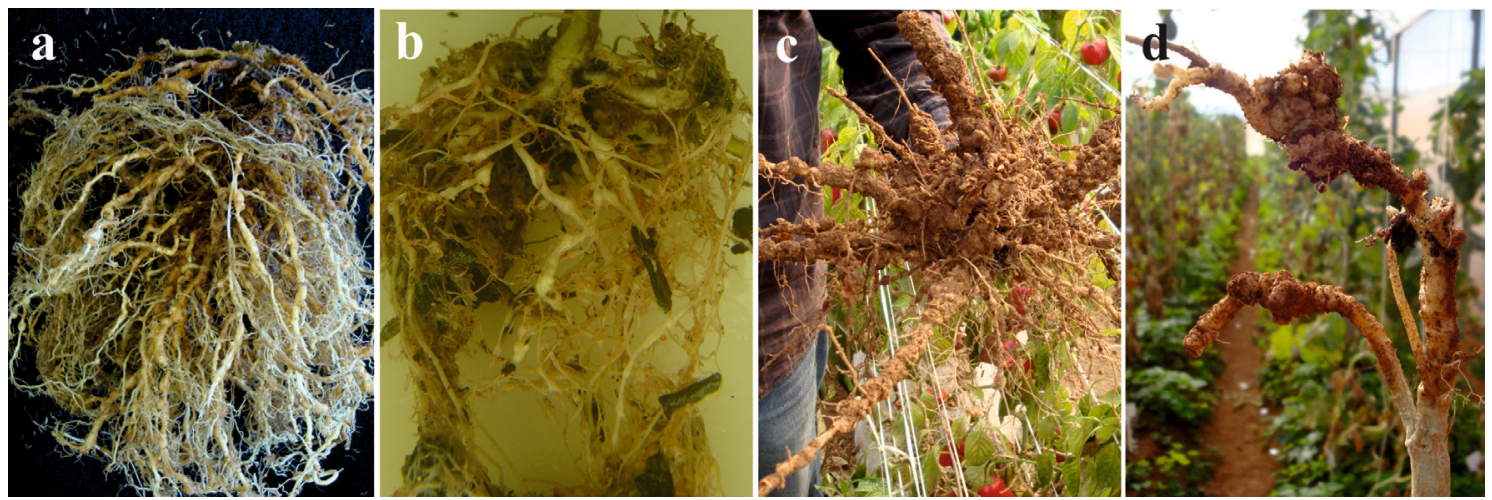

Figure 3: (a) Severe symptoms caused by Meloidogyne spp. infection in gilo roots; (b) cabbage roots; (c) pepper roots; (d) and melon roots

Among the fruits, important root-knot hosts include banana (Musa spp.), grapevine (Vitis vinifera), and papaya (Carica papaya), and infection may cause up to 33\% and 50\% losses in melon (Cucumis melo) and watermelon production, respectively [32]. A rootknot nematode species that has been recently highlighted in vegetable production is Meloidogyne enterolobii (syn. M. mayaguensis) (European 2014). The major problem in terms of M. enterolobii infection in horticulture has been their fast propagation and dissemination in the soil, with records all over the world. This root-knot species has a wide host range, being able to overcome the resistance of many horticultural products. In France and Switzerland, M. enterolobii was detected in 1983 as an important problem in tomato production areas [33]. In Northeast Brazil, M. enterolobii was described in 2001 in guava production areas and later as infecting green pepper rootstock and cucumber in other areas [34]. Its presence was also reported in jalapeño pepper and watermelon in Mexico [35]. Other economically important M. enterolobii hosts are aubergine, bean, sweet potato, and ornamental plants, such as Brugmansia and Clerodendron.

\section{Pratylenchus spp. (Root lesion nematode - RLN)}

Pratylenchus pratensis was first described in 1880 [30]. Currently, the genus Pratylenchus is found worldwide, with more than 75 species already described [36]. Also known as lesion nematodes, they compose an important group of root migratory ectoendoparasites in a great variety of hosts. The damage caused by lesion nematodes in roots and tubers is distinct, as they do not produce a feeding site like cyst or root knot nematodes. Pratylenchus attack creates galleries in host tissues due to their free movement through the root and feeding in the plant cortex, resulting in dark spots or lesions. This disparity among genera likely occurs because the ability of members of the nematode phylum to parasite plants appears to have arisen through several independent evolution events [37,38].

Reproduction in members of the Pratylenchus genus may be sexual or asexual depending on the species. Pratylenchus neglectus, $P$. thornei and $P$. brachyurus reproduce by parthenogenesis, while male and female $P$. penetrans must mate before producing fertile eggs. Pratylenchus females lay an average of one egg per day, and, at appropriate temperatures, the cycles range from 45 to 65 days $[39,40]$. Once juveniles emerge from the eggs, approximately one week after egg deposition, all stages are capable of infecting and feeding from plant roots. Lesion nematode damage in plant roots is generally evidenced by necrosis and death, as exemplified in pepper (Figure 4).
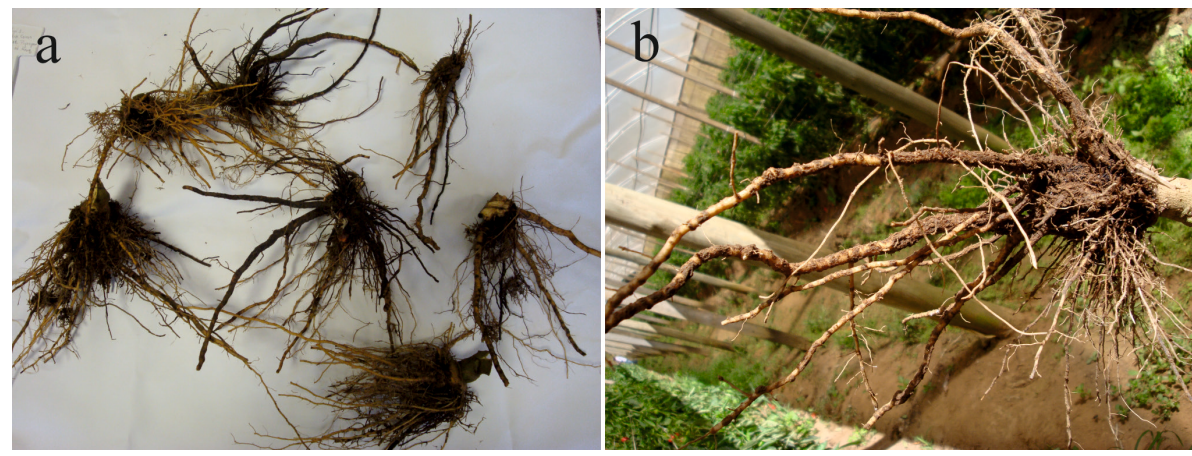

Figure 4: (a) Necrosis Symptoms in Pepper Roots caused by pratylenchus spp. Lesion Nematode Infection in capsicum annuum (b) and capsicum baccatum

The most economically important species in potato and tubers worldwide are P. penetrans and P. scribneri [25]. These root lesion nematodes usually get inside tubers using lenticels and then invade the surrounding tissue, causing variable-sized circular lesions (Figure 5) [41]. Although these lesions are usually superficial, restricted to the outer $0.5 \mathrm{~mm}$ of the tuber, this damage always decreases the marketable quality of the product [30]. The symptoms of root lesion nematode infection in yam are more severe, and infection is characterized by a dehydrated aspect, cracked skin, and softness of the tuber when pressed. 

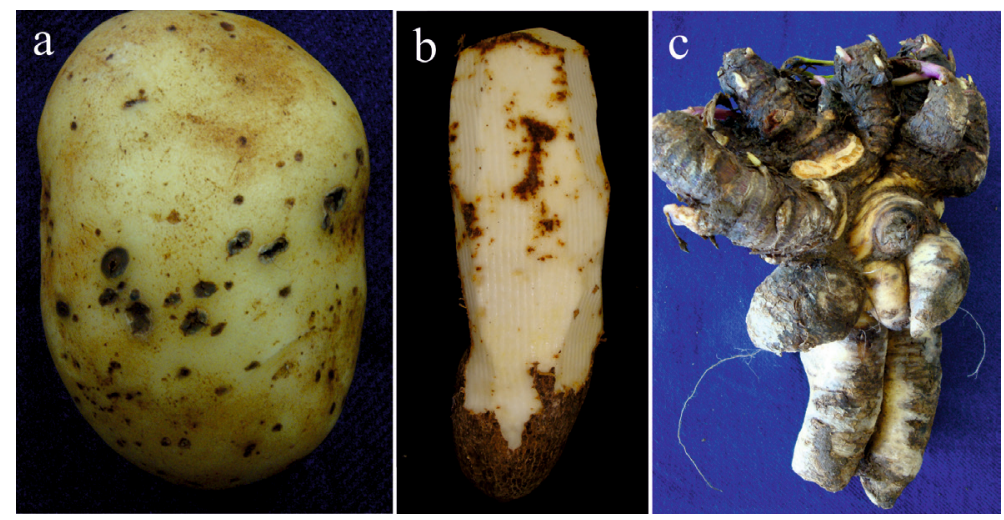

Figure 5: (a) Tuber Symptoms caused by Pratylenchus spp. Infection shows Necrotic Spots all over in Potato;

(b) Peeled yam; (c) and Peruvian carrot

Pratylenchus attack in broadleaf plants, especially lettuce, results in a reduction in growth, yellowing, and small head formation, preventing their sale at market [29]. Peanut (Arachis hypogaea L.) is an important oilseed horticulture crop and showed a yield of 39.3 million tons in 2012 [42]. Indeed, root lesion nematodes have caused significant losses in peanut production worldwide, infecting roots and causing above-ground symptoms, such as a clustered arrangement of stunted plants, chlorosis and premature senescence [25]. However, peanut yield losses caused by nematodes are most often associated with damage to pods and pegs. Peanut pods infected by Pratylenchus can be identified by the presence of small brown tunnels (tan spots with dark centres) in the shells and shrivelled pegs. Root lesion nematodes have also been associated with losses in fruit, such as grape, banana, pineapple, and soursop. In soursop, Pratylenchus causes a symptom known as sudden death, characterized by dark lesions on the plant neck region, right below the soil [43].

\section{Radopholus spp. (Burrowing nematode - BWN)}

The phytopathogenic Radopholus genus is known as burrowing nematode, and several species compose this migratory endoparasitic group. The Radopholus genus has a relatively wide host range of more than 300 plant species, and the most important species for horticulture are $R$. citri and $R$. similis, which can infect citrus and banana, respectively. Burrowing nematode causes damage worldwide and can be found especially in tropical and subtropical areas [44]. Radopholus presents similar behaviour and life cycles to those of Pratylenchus spp. Burrowing nematode females and juveniles are highly infective and complete their life cycles within the host root cortical cells, causing root cell death and necrosis. Radopholus reproduces sexually; 2 to 5 eggs are laid per day in the root tissues, and the entire life cycle can be completed in 3 weeks under favourable conditions [45]. The most characteristic symptoms of Radopholus-infected plants are lesions and burrows in the roots, a result of their movement inside the tissue, causing destructive damage and malnutrition [25].

The disease caused by Radopholus similis in banana is known as 'blackhead' due to feeding on the root cortex, which can cause internal tissue necrosis. Other burrowing nematode infection symptoms in banana are impaired or stunted growth, incomplete or yellowing leaves, small bunches and uprooting [43]. Radopholus similis has already been recorded as the cause of $100 \%$ losses in Cavendish banana [24]. Radopholus similis is also a problem for ginger, and the symptoms are similar to those seen in Meloidogyne infection. Radopholus citri and $R$. similis can be serious problems for citrus. $R$. citri damage is considered to be an important issue, causing stunted growth in citrus and reducing fruit production in terms of quantity and quality.

\section{Ditylenchus spp. (Stem and Bulb Nematode - SBN)}

Stem and bulb nematodes, as Ditylenchus spp. nematodes are called, are a group of migratory endoparasitic nematodes that can infect plant stems and leaves [46]. They are devastating phytonematodes that can be found worldwide, especially in temperate areas [47]. Outside of eggs, all stem and bulb nematode life stages are infective. Under adverse conditions, Ditylenchus species are able to produce a dormant structure known as 'nematode wool', which is a bundle of juveniles, to survive [48,49]. The plant symptoms
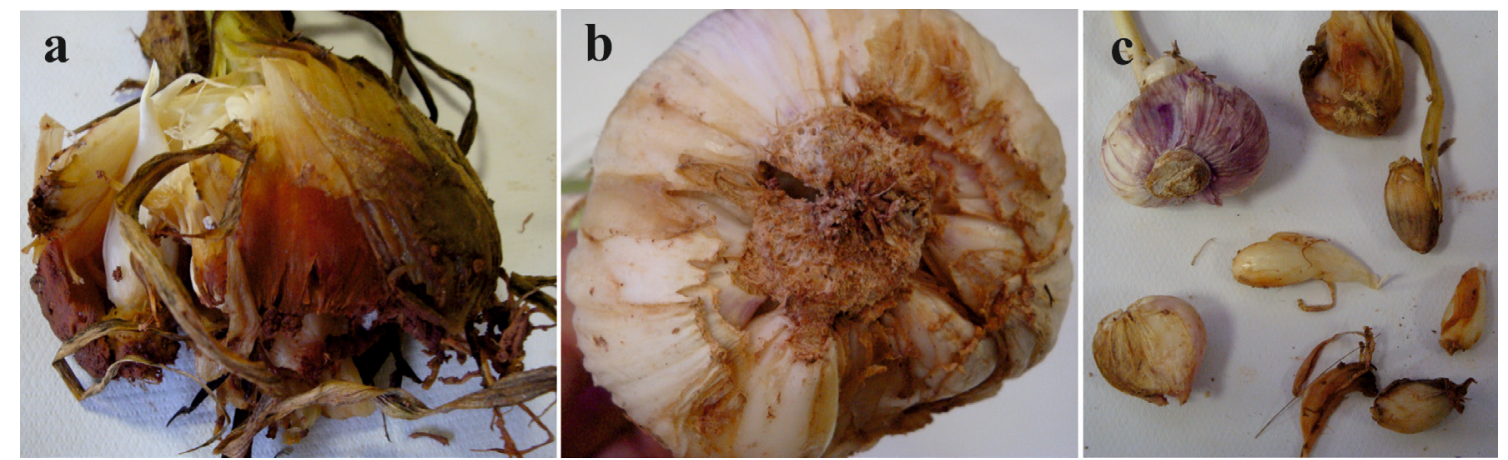

Figure 6: (a) Symptoms caused by Ditylenchus spp. Infection in Garlic. Twisted garlic bulb; (b) Rough-Looking bulb; (c) and Garlic Clove 
of Ditylenchus infection are usually swollen, distorted stems, with reddish-brown to black lesions [50]. This genus can be a serious problem in potato crops, with $D$. dipsaci and $D$. destructor causing dry rot, whereas the latter species causes more severe damage [49]. However, horticultural losses caused by Ditylenchus have been most associated with Allium production (Figure 6) [51].

In onion, seedlings infected by $D$. dipsaci became gnarled and misshapen, often resulting in plant death. Throughout the crop cycle, onion leaves fall, bulbs become empty and roots yellow. In garlic, the symptoms are dwarfism, swelling, and extensive longitudinal splitting of the cotyledons and leaves, which are short and thick and often have brown or yellowish spots due to discoloration of the tissues, and swelling above the bulb in the pseudo-stem, causing the cigar formation [52]. Recently, D. arachis was associated with peanut pod rot, causing brown discoloured pods, pegs, hull endocarps, and smaller and shrunken seeds [50].

\section{Other important nematode genera}

There are many other important nematode genera that affect horticultural crops, such as Heterodera, Globodera, Rotylenchus, Tylenchulus, Helicotylenchus and Xiphinema. Heterodera species, also known as cyst nematodes (CYN), are sedentary endoparasitic nematodes that can infect cabbage, carrot, broccoli, and other crops. Cyst nematodes also cause very important damage in sugar beet. In guava production, $H$. dihystera has been reported as an important pest. Golden cyst nematodes (GCN), species of the Globodera genus, have a similar behaviour to that of Heterodera as sedentary endoparasites, but their cysts are globose in shape. The most important species of this genus are G. rostochiensis and G. pallida. Globodera is known as especially important in potato crops.

The Rotylenchulus genus, also known as reniform nematodes (RNN) due to their kidney-like shape, is most represented by the Rotylenchulus reniformis species. It is a sedentary semi-endoparasite that is commonly associated with the rhizosphere of several horticultural crops, especially in tropical and subtropical soils. Rotylenchulus reniformis has been a threat to pineapple production areas, suppressing yields and causing slight to severe stunting and reddening of the leaves. Citrus nematodes (CTN), species of the Tylenchulus genus, have a similar behaviour to that of Rotylenchulus as a sedentary semi-endoparasite, and they have a range of more restricted hosts. Tylenchulus semipenetrans is the most important species in this genus, and it is responsible for the slow decline of citrus. These symptoms are characterized by a gradual decline in growth, leaf health and size, fruit size and quality over the years.

Helicotylenchus is a genus that contains nematodes called spiral nematodes (SRN) due their bodies being wrapped into a spiral format. It is a migratory ecto-/endoparasite commonly associated with turfgrasses and other grass hosts. In addition, spiral nematodes can cause crop damage in banana and other fruit trees. The Xiphinema nematode genus can cause important yield losses in horticultural crops when found in high population numbers. These migratory ectoparasites are also known as dagger nematodes (DGN) and can seriously affect cashew tree and vine crops. The damage caused by these nematodes also occurs due to their involvement in virus transmission.

Members of the Aphelenchoides genus, also known as leaf and bud nematodes, show migratory behaviour, living in and feeding upon the aerial portions of a plant but are rarely associated with the soil. They cause serious damage to alfalfa and strawberries and are an emerging problem for gardeners because of this broad host range and their ability to spread quickly in hostas and many ornamentals $[53,54]$. The nematode feeds on mesophyll cells by infecting buds and the stomata of young leaves. The infected leaf areas become chlorotic and subsequently necrotic, usually surrounded by large vein structures. A. ritzemabosi is commonly called the chrysanthemum foliar nematode, and A. fragariae is called strawberry crimp. On strawberry and Anthurium seedlings, A. fragariae can easily lead to plant death.

\section{Auspicious Strategies in Horticulture}

Therefore, now the most important concern is how many horticultural crops are and will be grown in the near future, even facing this strong opponent? [44]. Nematicides have been used in many countries, but they are strongly limited by their high prices and low efficiency. However, this is not the most important concern. Some of the most effective nematicides have disadvantages not for being expensive but because they are extremely toxic to human and animals. As long as people are aware of environmental protection, intensive research efforts for the development eco-friendly alternative strategies in nematode management have become imperative [15]. Indeed, the future of nematicides in horticulture will depend on new compounds that are effective and environmentally safe. Crop rotation is another alternative that can be used to decrease phytonematode populations in the soil. This technique uses some resistant plants species as a 'trap' to attract the nematodes, especially Crotalaria spectabilis [55]. However, many of the resistant species that can be applied as a 'trap' in crop rotation are not economically profitable. Meanwhile, most of the researchers involved in creating a solution for plant nematode infection and consequent losses endorse that the genetic approach for plant tolerance or resistance seems to be the best alternative [56].

Several dominant, recessive and co-dominant resistance $(\mathrm{R})$ genes, which affect nematode virulence, and quantitative trait loci (QTLs), which confer strong resistance, have been discovered in different horticulture plants, especially those for sedentary nematodes, such as the Mi gene in tomato and the $\mathrm{N}$ gene in pepper against Meloidogyne spp. [57]. The Mi gene, well described in the literature for incompatible plant-nematode interactions, confers resistance to $M$. incognita, M. javanica, M. arenaria and M. 
enterolobii in tomato (Solanum lycopersicum L.) [58]. However, the effect of this gene depends on the root-knot nematode species or race $[59,60]$. So far, the $M i$ gene has been the main target for breeding programmes in attempts to develop complete resistance against Meloidogyne spp. in tomato cultivars.

Paal and co-workers [61] described the gene Gro1-4 in tomato as being able to confer resistance to G. rostochiensis (pathotype Ro1). The psoRPM1 gene in Prunus sogdiana shows similar structure and high homology with the Mi-1.2 gene, and it seems to play an important defence function against the root-knot nematode, mainly in the phloem or pericycle [62]. Stone fruit crops, Prunus spp., are severely damaged by root-knot nematodes (RKN), and some resistance genes have been identified, such as Ma and Rjap (Prunus cerasifera - plums), RMia (Prunus persica - peach) and RMja (Prunus dulcis - almonds). The RMia gene confers resistance to Meloidogyne incognita and Meloidogyne arenaria in peach genotypes [63]. However, no gene seems to confer a resistance spectrum as complete as the $M a$ gene in plums. $M a$ has been tested against more than 30 mitotic and meiotic reproduction strategies in Meloidogyne species, and it triggers a hypersensitive-like reaction (HLR) that results in high-level resistance, even at high temperatures [64].

Mao et al., reported [65] that CaRKNR was induced by M. incognita in pepper plants (Capsicum annuum L.) and by virus-induced gene silencing (VIGS), and its function was correlated with resistance against root-knot nematodes. A myo-inositol-1-phosphate synthase gene, MIPS1, has been shown to improve tolerance to abiotic stresses in several plant species, such as salt and drought stress. This gene has also been shown to be involved in stem nematode resistance (Ditylenchus destructor Thorne) in sweet potato (Ipomoea batatas) [66] tuberosum, which confers resistance to Globodera pallida, and rkn1 from Gossypium hirsutum, which confers resistance to $M$. incognita.

There has been remarkable progress in quantitative nematode resistance analyses in horticulture. In analyses of three diverse sources of carrot (Daucus carota) resistance against Meloidogyne incognita, Parsons et al., [67] were able to map its genetic resistance. The analysis revealed five non-overlapping QTLs on chromosomes 1, 2, 4, 8, and 9, conditioning resistance in the segregating population from three different crossings. However, the consensus map showed one QTL present in the same region of chromosome 8 in all three populations. The resistance of horticultural crops against migratory nematodes seems to occur in the first identification steps. The dagger nematode, Xiphinema index, attacks the deep perennial system of grape roots. The infection causes the depression of plant growth through root damage. Chin-Feng Hwang et al. [68] demonstrated that resistance to X. index was highly controlled by a major quantitative trait locus, XiR1, in hybrid lines from Vitis arizonica/girdiana.

Last but not least, effector elucidation is also an auspicious approach towards nematode control in horticulture. Although plantparasitic nematode behaviour shows a variety of groups and life styles, morphological features have been successfully applied as an evaluative approach to establish the phylogeny of phylum Nematoda [38]. All nematode species present a stylet that is not just for feeding but also used for injecting secreted proteins, called effectors or parasitism proteins, which are produced in nematode oesophageal gland cells and affect the host apoplast and cytoplasm. These molecules can affect several plant processes, such as cell cycle activation, plant signalling, and cell morphogenesis, allowing infection success. The understanding of the factors that allow nematode harmfulness, plant susceptibility or immunity and host range can be crucial for developing new strategies for controlling nematodes and other important phytopathogens [69].

Currently, there are 15 phytonematode species compound sequence databases of ESTs and genes, including six for Meloidogyne and five for members of the migratory group, such as Pratylenchus penetrans [70]. It is clear that this information is accelerating the identification of new nematode parasitism proteins. Since 2010, more than 11 effectors in several nematode species have been identified, such as GrVAP1, a venom allergen protein, in G. rostochiensis [71], Hs10A06, related to defence suppression, in H. schachtii [72] and MiCRT, a calreticulin also related to defence suppression, in M. incognita [73]. Rs-cr, a calreticulin from Radopholus similis, is related to pathogen reproduction and pathogenicity in tomato. After the treatment of juveniles with Rs-crt dsRNA for $36 \mathrm{~h}$, researchers showed that transgenic tomato plant resistance to $R$. similis was significantly improved, affecting pathogen reproduction and pathogenicity [74]. 14-3-3 protein and RBP-1 protein are new effector candidates from the beet cyst nematode, H. schachtii [75].

Some effectors can be identified particularly during their interaction with horticultural crops. The gene silencing of Cg-1 from $M$. javanica leads to the acquisition of virulence in tomato [76]. As demonstrated before, $M i-1$ confers resistance against several species of root-knot nematode in tomato; however, a unique $M$. javanica strain is able to infect Mi-1 plants. After silencing a candidate nematode effector gene, $\mathrm{Cg}$-1, in nematode juveniles of the $\mathrm{Mi}$-1-avirulent strain, the virulent progeny are able to infect tomato plants carrying the $\mathrm{Mi}-1$ gene, suggesting that $\mathrm{Cg}$-1 is responsible for virulence and is required in the nematode for $\mathrm{Mi}$ 1-mediated resistance. Li et al., [74] performed studies with tomato and described a nematode calreticulin, Rs-crt, in Radopholus similis. After the treatment of juveniles with Rs-crt dsRNA for $36 \mathrm{~h}$, they showed that the resistance of transgenic tomato plants to $R$. similis was significantly improved, affecting pathogen reproduction and pathogenicity.

Thorpe et al., [77] performed genomic characterization for Globodera pallida effector identification. Also known as the potato cyst nematode, 128 orthologues of effectors were identified from other nematodes, as well as 117 novel effector candidates. Eves-van den Akker et al., [78] provides the identification and characterization of a novel group of hypervariable extracellular effectors, termed HYP, in the potato cyst nematode, G. pallida. HYP expression was identified in secretory cells by in situ hybridization and detected the protein in apoplastic host cells by immunochemistry. In addition, effector silencing by RNAi in planta resulted in a reduction in nematode infection. 
Fosu-Nyarko et al., [75] performed an analysis of the transcriptome of the beet cyst nematode, $H$. schachtii, looking for effector candidates. After sequence comparison analyses with other already described plant parasitic nematode species effectors, 30 similar $H$. schachtii transcripts were found. Among these identified transcripts were new effector sequences for this species, such as a calreticulin, 14-3-3 protein and RBP-1 protein. This protein family includes highly conserved eukaryote-specific proteins involved in several cellular and biochemical processes through interaction with phosphorylated target proteins. As described in other phytonematodes, 14-3-3 proteins can play several roles in host-parasite communication.

Finally, it is clear how phytonematodes are an important threat to the world's horticulture. However, even with many studies focusing on the horticultural losses caused by this enemy, there is still a lot to be overcome. Although their detection and symptoms are already possible and well known, new methods for faster diagnosis and control should be developed. We see how horticulture is complex, diverse, interactive, and powerful, but also for these reasons, further studies needs to be directed in order to identify resistant genes and nematode effectors to rise up new management approaches.

\section{Conflict of Interest Statement}

The authors declare that the research was conducted in the absence of any commercial or financial relationships that could be construed as a potential conflict of interest.

\section{Acknowledgements}

We wish to thank our laboratory co-workers from EMBRAPA Vegetables and Soybean for good support and the National Council for the Improvement of Higher Education (CAPES) for the granting of a scholarship to support this study. Our studies are funded by EMBRAPA - Brazilian federal government.

\section{References}

1. Dixon GR, Aldous DE (2014) Horticulture: Plants for People and Places In: Production Horticulture. Springer Netherlands, Netherlands.

2. Janick J (2014) History of Agricultural and Horticultural Technology in Asia. Purdue Univ 2014: 1-19.

3. Piperno DR (2011) The Origins of Plant Cultivation and Domestication in the New World Tropics. Curr Anthropol 52: S453-70.

4. Shry C, Reiley E (2015) Introductory Horticulture (9th Edn) Springer India, India.

5. Nicola S, Fontana E (2010) Global Horticulture: Challenges and Opportunities. Acta Hortic 10.17660/ActaHortic.2010.856.5

6. Smith S (2014) Global Horticulture (2010 - 2014) - Pink and Healthy.

7. FAO of the UN (2018) World Food and Agriculture: Statistical PocketBook.

8. IBIS World (2015) Global Fruit \& Vegetables Processing, New York, USA.

9. Simmons J (2015) ENOUGH: Building a Food-Secure Tomorrow.

10. Ravichandra NG (2014) Horticultural Nematology. Springer, New Delhi, India.

11. Dixon GR, Aldous DE (2014) Fruit and Vegetables and Health: An Overview In: Horticulture: Plants for People and Places, Volume 3: Social horticulture. Springer Netherlands, Netherlands.

12. Vivero Pol JL (2014) The Food Commons Transition: Collective actions for food and nutrition security. In: Food Sovereignty: A Critical Dialogue, Netherlands. 13. Rehman B, Ganai MA, Parihar K, Siddiqui MA, Usman A (2012) Management of Root Knot Nematode, Meloidogyne incognita Affecting Chickpea, Cicer arietinum for Sustainable Production. Biosci Int 1: 1-5.

14. Elling AA (2013) Major Emerging Problems with Minor Meloidogyne Species. Phytopathol 103: 1092-102.

15. Rao MS, Umamaheswari R, Priti K, Rajinikanth R, Grace GN, et al. (2016) Role of Biopesticides in the Management of Nematodes and Associated Diseases in Horticultural Crops. In: Plant, Soil and Microbes. Springer. 117-48.

16. Jones MGK, Fosu-Nyarko J (2014) Molecular biology of root lesion nematodes (Pratylenchus spp.) and their interaction with host plants. Ann Appl Biol 164: $163-81$.

17. Jones JT, Haegeman A, Danchin EGJ, Gaur HS, Helder J, et al. (2013) Top 10 plant-parasitic nematodes in molecular plant pathology. Mol Plant Pathol 14: 946-61.

18. Palomares-Rius JE, Hedley PE, Cock PJ, Morris JA, Jones JT, et al. (2012) Comparison of transcript profiles in different life stages of the nematode Globodera pallida under different host potato genotypes. Mol Plant Pathol 13: 1120-34.

19. Pedroche NB, Villaneuva LM, Waele D De (2013) Plant-parasitic nematodes associated with semi-temperate vegetables in the highlands of Benguet Province, Philippines. Arch Phytopathol Plant Prot 46: 278-94.

20. Xalxo PC, Karkun D, Poddar AN (2013) Rhizospheric Fungal Associations of Root Knot Nematode Infested Cucurbits: In vitro Assessment of Their Nematicidal Potential. Res J Microbiol 8: 81-91.

21. Ibrahim IKA, Massoud SI (1974) Development and Pathogenesis of a Root-Knot Nematode, Meloidogyne javanica. Proc Helm Soc Wash 41: 68-72.

22. Maleita C, Curtis R, Abrantes I (2012) Thermal requirements for the embryonic development and life cycle of Meloidogyne hispanica. Plant Pathol 61: 1002-10.

23. Favery B, Quentin M, Jaubert-Possamai S, Abad P (2016) Gall-forming root-knot nematodes hijack key plant cellular functions to induce multinucleate and hypertrophied feeding cells. J Insect Physiol 84: 60-9.

24. Pinheiro JB, Silva GO, Pereira RB (2015) Nematoids in potato culture [Nematoides na Cultura da Batata] Embrapa Hortaliças, Brazil.

25. Bridge J, Starr JL (2007) Plant Nematodes of Agricultural Importance: A Colour Handbook (1st Edn) CRC Press, USA.

26. Vovlas N, Mifsud D, Landa BB, Castillo P (2005) Pathogenicity of the root-knot nematode Meloidogyne javanica on potato. Plant Pathol 54: 657-64. 
27. Wesemael WML, Moens M, Viaene N, Taning LM (2014) Life cycle and damage of the root-knot nematode Meloidogyne minor on potato, Solanum tuberosum. Nematol 16: 185-92.

28. Okorocha EOA, Ogbuji RO, Ijeoma OF, Okorocha CG (2014) Relationship between Root-Knot Nematode Meloidogyne javanica Inoculum Densities and Ginger ( Zingiber officinale Roscoe ). Sch Acad J Biosci 2: 809-12.

29. Pinheiro JB, Amaro GB, Pereira RB (2010) Occurrence and control of nematodes in leafy vegetables [Ocorrência e controle de nematoides em hortaliças folhosas] Embrapa, Brazil.

30. Davis EL, MacGuidwin AnE (2000) Lesion nematode disease. Plant Heal Instr 10.1094/PHI-I-2000-1030-02.

31. Mitkowski NA, Abawi GS (2003) Root-knot nematode. Plant Heal Instr 10.1094/PHI-I-2003-0917-01.

32. Sikora RA, Fernández E (2005) Nematode Parasites of Vegetables (3rd Edn) In: Plant parasitic nematodes in subtropical and tropical agriculture, CABI Publishing, UK.

33. Moens M, Viaene N, Wesemael W (2011) Root-knot nematodes (Meloidogyne spp.) in Europe. Nematol 13: 3-16.

34. Wilcken SRS, Rosa JM, Westerich JN, Garcia MJDM, Cardoso AII (2013) Reproduction of Meloidogyne enterolobii in rootstocks and cucumber hybrids. Hortic Bras 31: S0102-05362013000400018.

35. Villar-Luna E, Gómez-Rodríguez O, Rojas-Martínez RI, Zavaleta-Mejía E (2016) Presence of Meloidogyne enterolobii on Jalapeño pepper (Capsicum annuum L .) in Sinaloa, Mexico. Helminthologia 53: 155-60.

36. Araya TZ, Padilla WP, Archidona-Yuste A, Cantalapiedra-Navarrete C, Liébanas G (2016) Root-lesion nematodes of the genus Pratylenchus (Nematoda: Pratylenchidae) from Costa Rica with molecular identification of P. gutierrezi and P. panamaensis topotypes. Eur J Plant Pathol 145: $973-98$.

37. Bird DM, Jones JT, Opperman CH, Kikuchi T, Danchin TGJ (2015) Signatures of adaptation to plant parasitism in nematode genomes. Parasitology 142: S71-84. 38. Quist CW, Smant G, Helder J (2015) Evolution of Plant Parasitism in the Phylum Nematoda. Annu Rev Phytopathol 53: $289-310$.

39. Ryss AY (2002) Genus Pratylenchus Filipjev : multientry and monoentry keys and diagnostic relationships (Nematoda: Tylenchida: Pratylenchidae). Zoosystematica Ross 10: 241-55.

40. Collins S, Wilkinson C (2015) Pratylenchus penetrans: a horticulturally significant root lesion nematode.

41. Pinheiro JB, Amaro GB, Pereira RB (2011) Nematoides in Capsicum chili peppers [Nematoides em pimentas do gênero Capsicum] Embrapa Hortaliças, Brazil. 42. Chu Y, Guimarães LA, Wu CL, Timper P, Holbrook CC, et al. (2014) A Technique to Study Meloidogyne arenaria Resistance in Agrobacterium rhizogenes -Transformed Peanut. Plant Dis 98: 10.1094/PDIS-12-13-1241-RE.

43. Dias-Arieira CR, Molina R de O, Costa AT (2008) Disease-Causing Nematodes In Fruit Trees (Nematóides Causadores de Doenças em Frutíferas). Agro Ambient 2: doi: 10.18227/1982-8470ragro.v2i1.230.

44. Luc M, Bridge J, Sikora RA (2005) Reflections on Nematology in Subtropical and Tropical Agriculture. In: Luc M, Sikora RA, Bridge J (eds) Plant parasitic nematodes in subtropical and tropical agriculture. CABI, Wallingford, UK 1-12.

45. Brooks FE (2008) Burrowing Nematode Diseases. Plant Heal Instr 42: 142-5.

46. Peng H, Gao B, Kong L, Yu Q, Huang W, et al. (2013) Exploring the Host Parasitism of the Migratory Plant-Parasitic Nematode Ditylenchus destuctor by Expressed Sequence Tags Analysis. PLoS One 8: 10.1371/journal.pone.0069579.

47. Maule A, Curtis R (2010) Parallels Between Plant and Animal Parasitic Nematodes.

48. Bosher JE (1960) Longevity in vitro of Ditylenchus dipsaci (Kiihn) Filipjev from Narcissus. The Helminthological Society of Washington. Washington, USA 1960: $127-8$

49. Mwaura P, Niere B, Vidal S (2015) Resistance and tolerance of potato varieties to potato rot nematode (Ditylenchus destructor) and stem nematode (Ditylenchus dipsaci) Ann Appl Biol 166: 257-70.

50. Zhang SL, Liu GK, Janssen T, Zhang SS, Xiao S, et al. (2014) A new stem nematode associated with peanut pod rot in China: morphological and molecular characterization of Ditylenchus arachis n. sp. (Nematoda: Anguinidae). Plant Pathol 63: 1193-206.

51. Fan W, Wei Z, Zhang M, Ma P, Liu G, et al. (2015) Resistance to Ditylenchus destructor Infection in Sweet Potato by the Expression of Small Interfering RNAs Targeting unc-15, a Movement-Related Gene. Phytopathology 105: 1458-65.

52. Pinheiro JB, Ferreira AD, Carvalho D, Pereira RB (2014) Nematodes in garlic and onion culture (Nematoides na cultura do alho e cebola) Embrapa Hortaliças, Brazil.

53. Feng H, Shao Y, Wei LH, Gao CY, Zhou YJ (2014) The white-tip nematode, Aphelenchoides besseyi, exhibits an auxin-orientated behaviour affecting its migration and propagation. Nematol 16: 10.1163/15685411-00002812.

54. Jagdale GB, Grewal PS (2006) Infection Behavior and Overwintering Survival of Foliar Nematodes, Aphelenchoides fragariae, on Hosta. J Nematol 38: 130-6. 55. Wesemael W, Viaene N, Maurice Moens (2011) Forum article Root-knot nematodes (Meloidogyne spp.) in Europe. Nematol 13: 10.1163/138855410X526831. 56. Khan Z, Gawade BH, Kandan A (2015) Resistant Cultivars: Environment-friendly Management of Plant Parasitic Nematodes. In: ICAR-National Bur. Plant Genet. Resour. New Delhi, India.

57. Devran Z, Göknur A, Mesci L (2016) Development of molecular markers for the Mi-1 gene in tomato using the KASP genotyping assay. Hortic Environ Biotechnol 57: 156-60.

58. Kiewnick S, Dessimoz M, Franck L (2009) Effects of the Mi-1 and the N root-knot nematode-resistance gene on infection and reproduction of Meloidogyne enterolobii on tomato and pepper cultivars. J Nematol 41: 134-9.

59. Brown CR, Mojtahedi H, Santo GS, Williamson VM (1997) Effect of the Mi Gene in Tomato on Reproductive Factors of Meloidogyne chitwoodi and M. hapla. J Nematol 29: 416-9.

60. Tzortzakakis EA, Trudgill DL, Phillips MS (1998) Evidence for a Dosage Effect of the Mi gene on Partially Virulent Isolates of Meloidogyne javanica. J Nematol 30: 76-80.

61. Paal J, Henselewski H, Muth J, Meksem K, Menéndez CM, Salamini F, Ballvora A, Gebhardt C (2004) Molecular cloning of the potato Gro1-4 gene conferring resistance to pathotype Ro1 of the root cyst nematode Globodera rostochiensis, based on a candidate gene approach. Plant J 38: 285-97.

62. Li F, Zhou L, Xiao F, Liao K, Hu J (2011) Characterization of the psoRPM1 gene for resistance to root-knot nematodes in wild myrobalan plum (Prunus sogdiana). Afr J Biotechnol 10: 10.5897/AJB11.1282. 
63. Duval H, Hoerter M, Polidori J, Confolent C, Masse M, et al. (2014) High-resolution mapping of the RMia gene for resistance to root-knot nematodes in peach. Tree Genet Genomes 10: 297-306.

64. Esmenjaud D, Van Ghelder C, Polidori J, Khallouk S, Duval H (2015) Biological Features, Positional Cloning and Functional Validation of the Ma Gene for Complete-Spectrum Resistance to Root-Knot-Nematodes in Prunus. Acta Hortic 33-8.

65. Mao Z, Zhu P, Liu F, Huang Y, Ling J, et al. (2015) Cloning and functional analyses of pepper CaRKNR involved in Meloidogyne incognita resistance. Euphytica 205: 903-13.

66. Zhai H, Wang F, Si Z, Huo J, Xing L, et al. (2016) A myo-inositol-1-phosphate synthase gene, IbMIPS1, enhances salt and drought tolerance and stem nematode resistance in transgenic sweet potato. Plant Biotechnol J 14: 592-602.

67. Parsons J, Matthews W, Iorizzo M, Roberts P, Simon P (2015) Meloidogyne incognita nematode resistance QTL in carrot. Mol Breed 35: 114.

68. Chin-Feng H, Kenong Xu, Rong Hu, Riaz S, Walker MA (2014) Cloning and Characterization of the Dagger Nematode Resistance Gene XIR1. Acta Hortic 2014: 391-94.

69. Quentin M, Abad P, Favery B (2013) Plant parasitic nematode effectors target host defense and nuclear functions to establish feeding cells. Front Plant Sci 4: 53. 70. Rehman S, Gupta VK, Goyal AK (2016) Identification and functional analysis of secreted effectors from phytoparasitic nematodes. BMC Microbiol 16: 48.

71. Lozano-Torres JL, Wilbers RHP, Gawronski P, Boshoven JC, Finkers-Tomczak A, et al. (2012) Dual disease resistance mediated by the immune receptor Cf-2 in tomato requires a common virulence target of a fungus and a nematode. Proc Natl Acad Sci 10.1073/pnas.1202867109.

72. Hewezi T, Howe PJ, Maier TR, Hussey RS, Mitchum MG, et al. (2010) Arabidopsis Spermidine Synthase Is Targeted by an Effector Protein of the Cyst Nematode Heterodera schachtii. Plant Physiol 2010: 968-84.

73. Jaouannet M, Magliano M, Arguel MJ, Gourgues M, Evangelisti E, et al. (2013) The root-knot nematode calreticulin Mi-CRT is a key effector in plant defense suppression. Mol Plant Microbe Interact 26: 97-105.

74. Li Y, Wang K, Xie H, Wang YT, Wang DW, et al. (2015) A Nematode Calreticulin, Rs-CRT, Is a Key Effector in Reproduction and Pathogenicity of Radopholus similis. PLoS One 10: e0129351.

75. Fosu-Nyarko J, Nicol P, Naz F, Gill R, Jones MGK (2016) Analysis of the Transcriptome of the Infective Stage of the Beet Cyst Nematode, H. schachtii. PLoS One 11: e0147511.

76. Gleason CA, Liu QL, Williamson VM (2008) Silencing a candidate nematode effector gene corresponding to the tomato resistance gene Mi-1 leads to acquisition of virulence. Mol Plant-Microbe Interact 21: 576-85.

77. Thorpe P, Mantelin S, Cock PJ, Blok VC, Coke MC, et al. (2014) Genomic characterisation of the effector complement of the potato cyst nematode Globodera pallida. BMC Genomics 15: 923.

78. Eves-van den Akker S, Lilley CJ, Jones JT, Urwin PE (2014) Identification and Characterisation of a Hyper-Variable Apoplastic Effector Gene Family of the Potato Cyst Nematodes. PLoS Pathog 10: e1004391.

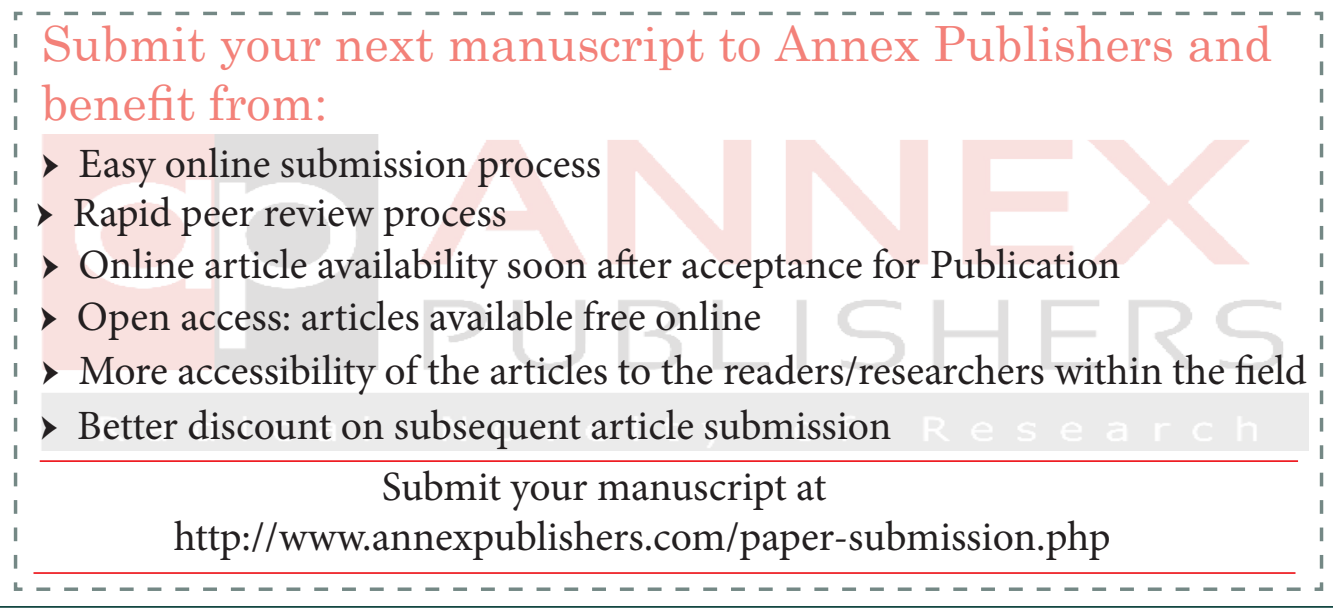

